\title{
Effects of Sodium Intake and Nephrotoxin Dose on Acute Renal Failure in the Young Rat
}

\author{
ANIL BIDANI ${ }^{(38)}$ AND PAUL CHURCHILL
}

Departments of Pediatrics and Physiology, Wayne State University School of Medicine, Detroit, Michigan, USA

\begin{abstract}
Summary
These experiments were undertaken to determine the differences between rats 3-4 and 7-8 wh of age with respect to the severity of acute renal failure (ARF) induced by two nephrotoxins, mercuric chloride $\left(\mathrm{HgCl}_{2}\right)$ and uranyl nitrate (UN). Two observations suggested that the younger rats might be more susceptible to ARF: ARF developed in response to a dose of $\mathrm{HgCl}_{2}$, which had no effect in the older rats, and mortality rates tended to be higher in the younger rats. Despite this possible age-related difference in susceptibility, increased sodium intake (giving $1 \% \mathrm{NaCl}$ rather than tap water to drink) had comparable protective effects in both models of nephrotoxin-induced ARF in rats of both ages.
\end{abstract}

\section{Speculation}

Despite previously described age-related differences in the distal tubular handling of sodium, increased sodium intake resulted in qualitatively similar protection from nephrotoxic acute renal failure in both 3-4 and 7-8-wk-old rats. Thus, the protective mechanism due to increased sodium intake may be a consequence of increased proximal tubular fluid flow.

Despite intensive investigation, the pathogenesis of acute renal failure (ARF) remains controversial (5-11, 14-17, 23, 25-28, 34, $35,37)$. A pathogenic role for the renin-angiotensin system has been postulated. This is based on the observations that, in certain experimental models of ARF, chronic sodium (Na) and potassium (K) loading suppress renal renin and reduce the severity of ARF whereas chronic $\mathrm{Na}$ deprivation augments renal renin and enhances the severity of ARF (14). Although we have confirmed that the severity of nephrotoxic ARF is inversely related to dietary $\mathrm{Na}$ intake and/or excretion, we have shown that this relationship is independent of changes in renal renin, at least in the mature rat (5). Very few data concerning ARF in the immature rat are available. Studies using the developing animal might provide some insights, inasmuch as there are age-related differences in the activity of the renin-angiotensin system and in the ability to handle volume expansion and dietary $\mathrm{Na}$ loads in many species, including the rat $(1,3-5,6,18-21,24,32,33)$. Any of these factors might affect the susceptibility to and/or the severity of ARF.

In a previous study of 2-, 4- and 8-wk-old rats, no pattern was found between the severity of mercuric chloride-induced ARF and either basal renal renin, plasma renin, or the increase in plasma renin $6 \mathrm{~h}$ after injection. However, there were age-related differences: mortality was highest in the 2-wk olds, and those that survived exhibited a delayed recovery, similar to what has been found in mature rats subjected to $\mathrm{Na}$ deprivation (5).

In the present studies, younger (3-4-wk old) and older (7-8-wk old) rats were compared with respect to the effect of varying dietary $\mathrm{Na}$ on two nephrotoxic models of ARF: mercuric chloride $\left(\mathrm{HgCl}_{2}\right)$ and uranyl nitrate (UN). In addition, the dose-response to $\mathrm{HgCl}_{2}$ of these two age groups were compared. It should be noted that since the weaning age of rats is 18-20 days, the younger rats of these studies were of necessity older than the youngest rats of the previous study (5).

\section{MATERIALS AND METHODS}

Sprague-Dawley rats, bred in our laboratory so that the exact postnatal ages were known, were studied at 3-4 wk of age (40-80 $\mathrm{g}$ body weight) and at $7-8 \mathrm{wk}$ of age (150-250 $\mathrm{g}$ body weight). All were weaned at 18-20 days of age.

Effect of dietary $\mathrm{Na}$. Each rat was put in a metabolic cage for 23 days before the experiments and given either a low Na diet (tap water plus "Na-free diet, Rat Modified," from Nutritional Biochemicals, Cleveland, $\mathrm{OH}$ ), a normal $\mathrm{Na}$ diet (tap water plus Purina Rodent Chow, from the Purina Company, St. Louis, MO), or a high $\mathrm{Na}$ diet $1 \% \mathrm{NaCl}$ rather than tap water, plus Purina Rodent (how). Fluid intake and urine output during the $24 \mathrm{~h}$ immediately preceeding the experiments were recorded. The urine was analyzed for $\mathrm{Na}$ and $\mathrm{K}$. Then randomly selected animals on each of the three dietary regimes, from both age groups, were sacrificed for the determinations of mean baseline blood urea nitrogen $(\mathrm{BUN})$ and serum creatinine $\left(\mathrm{S}_{\mathrm{Cr}}\right)$. The remaining rats were injected subcutaneously with $1 \mathrm{ml} / \mathrm{kg}$ body weight of either $4.7 \mathrm{mg} \mathrm{HgCl} / 2 / \mathrm{ml}$ or $2.5 \mathrm{mg} \mathrm{UN} / \mathrm{ml}$. Tail vein blood samples $(0.2$ $\mathrm{ml})$ were drawn on the second day after $\mathrm{HgCl}_{2}$ and on the second and fifth days after UN. On the fifth day after $\mathrm{HgCl}_{2}$ and on the seventh day after UN, animals were sacrificed and blood was obtained for the determinations of both BUN and $\mathrm{S}_{\mathrm{Cr}}$.

$\mathrm{HgCl}_{2}$ dose-response. Other rats given the normal $\mathrm{Na}$ diet were handled as described above except that they were injected with 1.5 or 3.0 , rather than with $4.7, \mathrm{mg} \mathrm{HgCl}_{2} / \mathrm{kg}$ body weight. In all cases, the volume was $1 \mathrm{ml} / \mathrm{kg}$ body weight.

Analyses. Methods for measurement of urinary $\mathrm{Na}$ and $\mathrm{K}, \mathrm{BUN}$ and $\mathrm{S}_{\mathrm{Cr}}$ have been described in recent publications from this laboratory $(5-8,10)$.

Statistics. All results are expressed as means \pm S.E. Analysis of variance (13) and Scheffe contrasts (36) were used to assess the statistical significance of differences between groups in multiple comparisons. Otherwise, the unpaired $t$ test was used (13).

\section{RESULTS}

Within each of the six major groups of rats (e.g., animals of two age groups were given either high, normal, or low $\mathrm{Na}$ diets), there were several subgroups (e.g., those sacrificed for baseline BUN and $\mathrm{S}_{\mathrm{C}}$, those injected with $\mathrm{UN}$ or with one of three doses of $\left.\mathrm{HgCl}_{2}\right)$. There were no statistically significant differences $(P>$ 0.05 ) between these subgroups within any of the six groups, with respect to fluid intake, urine output, and $\mathrm{Na}$ and $\mathrm{K}$ excretion rates measured during the $24-\mathrm{h}$ period preceeding the experimental day. Therefore, results for the subgroups were combined and mean values are presented in Table 1. In general, fluid intake, urine volume, and $\mathrm{Na}$ excretion all increased with increasing dietary $\mathrm{Na}$ in both age groups. Food intake was not measured in these animals. Thus, it is impossible to draw firm conclusions concerning the \% of dietary $\mathrm{Na}$ and $\mathrm{K}$ excreted in the urine. However, it is likely that food intake per unit body weight was higher, and therefore that $\mathrm{Na}$ and $\mathrm{K}$ intakes were higher, in the younger rats during this period of rapid weight gain $(3,4,6)$. This might explain why all groups of younger rats excreted more $\mathrm{K}$ 
than the corresponding groups of older rats and why the younger rats fed the normal $\mathrm{Na}$ diet excreted more than twice as much $\mathrm{Na}$ as the older rats.

BUN and $\mathrm{S}_{\mathrm{Cr}}$ were simultaneously determined at the time of sacrifice (baseline, 5 days after $\mathrm{HgCl}_{2}, 7$ days after $\mathrm{UN}$ ) or at the time of death. There were no significant differences in either baseline BUN or baseline $S_{\mathrm{Cr}}$ among the three major groups of older rats (high, normal, and low $\mathrm{Na}$ diets) or among the corresponding three major groups of younger rats $(P>0.05)$. Therefore, all baseline values were combined, and the means for the two age groups are shown in Figure 1. Also shown are the individual BUN and $\mathrm{S}_{\mathrm{Cr}}$ values measured either at sacrifice or death following $U N$ injection. An excellent correlation was found between the individual values for both the older rats $\left(r^{2}=0.85 ; \mathrm{y}=28.3 \mathrm{x}+13.7 ; P\right.$ $<0.001)$ and the younger rats $\left(r^{2}=0.88 ; \mathrm{y}=98.8 \mathrm{x}-65.4 ; P<\right.$ $0.001)$. However, the slopes of the relationships were clearly different between the two age groups $(P<0.001)$.

Figure 2 shows the correlation between $B U N$ and $S_{C r}$ at sacrifice or death following $\mathrm{HgCl}_{2}$ injection. Because of the large numbers of overlapping individual values, only the means of the various groups and subgroups were plotted. The coefficients of determination shown in Figure 2 were based on group and subgroup means; those based on individual values were equally high and significant $\left(r^{2}=0.90 ; \mathrm{y}=52.1 \mathrm{x}-27.2 ; P<0.001\right.$ for older rats and $\mathrm{r}^{2}=0.86 ; \mathrm{y}=95.1 \mathrm{x}-38.2 ; P<0.001$ for younger rats). The slopes for the two age groups were significantly different $(P<$ 0.001 , based on individual values).

Because of the excellent correlations in all cases between BUN and $\mathrm{S}_{\mathrm{Cr}}$, increases in either would be equally valid indices for reductions in glomerular filtration rate (GFR). However, for the purpose of assessing age-related differences in severity of ARF, it was decided that BUN was more meaningful. There was only a $20 \%$ difference between mature and immature rats with respect to baseline BUNs ( $14.6 \pm 0.4$ versus $18.2 \pm 0.6 \mathrm{mg} \%$, respectively) whereas there was a $35 \%$ difference between them with respect to baseline $\mathrm{S}_{\mathrm{Cr}}(0.80 \pm 0.02$ versus $0.52 \pm 0.02 \mathrm{mg} \%$, respectively). Thus $\mathrm{S}_{\mathrm{Cr}}$ would not discriminate between an older rat with a GFR $50 \%$ of normal and a younger rat with a GFR $33 \%$ of normal, whereas BUN might. BUN is not a completely satisfactory index due to possible age-related differences in diets. That this was not a major limitation is suggested by the lack of a significant difference between younger and older rats with respect to mean \% increase in BUN/\% increase in $\mathrm{S}_{\mathrm{Cr}}$ following the injection of $\mathrm{UN}$ or the $4.7 \mathrm{mg} / \mathrm{kg}$ dose of $\mathrm{HgCl}_{2}(1.40 \pm 0.1, n=95$ younger rats versus $1.6 \pm 0.1, n=92$ older rats; $P>0.05)$.

Figure 3 shows the development of ARF following UN injection. Mean baseline BUNs for each of the six major groups, as well as mean BUNs at 2, 5, and 7 days are shown. BUNs (baseline and 5 days) were compared using one-way analysis of variance and Scheffe contrasts. Mean control BUNs were not significantly

Table 1. Baseline weight, fluid intake, and urinary excretion

\begin{tabular}{|c|c|c|c|c|c|c|c|}
\hline Diet & Age group & Number & Wt (g) & $\begin{array}{l}\text { Fluid intake } \\
\text { (ml) }\end{array}$ & Urine $^{2}(\mathrm{ml})$ & $\begin{array}{l}\mathrm{U}_{\mathrm{Na}} \mathrm{V}^{2} \\
(\mu \mathrm{Eq})\end{array}$ & $\begin{array}{l}\mathrm{U}_{\mathrm{k}} \mathrm{V}^{2} \\
(\mu \mathrm{Eq})\end{array}$ \\
\hline High $\mathrm{Na}$ & $\begin{array}{l}7-8 \text { wk } \\
P \text { value }^{3} \\
3-4 \text { wk }\end{array}$ & 34 & $\begin{array}{l}195 \pm 6 \\
54+1\end{array}$ & $\begin{array}{l}24.6 \pm 1.6 \\
<0.01 \\
298+12\end{array}$ & $\begin{array}{c}13.2 \pm 0.8 \\
\mathrm{NS}\end{array}$ & $\begin{array}{c}3470 \pm 239 \\
<0.02\end{array}$ & $\begin{array}{c}952 \pm 61 \\
<0.001\end{array}$ \\
\hline Normal NA & $\begin{array}{l}7-8 \text { wk } \\
P \text { value } \\
3-4 \text { wk }\end{array}$ & $\begin{array}{r}80 \\
104\end{array}$ & $\begin{array}{l}195 \pm 3 \\
56 \pm 1\end{array}$ & $\begin{array}{c}13.2 \pm 0.6 \\
<0.001 \\
19.0 \pm 0.7\end{array}$ & $\begin{array}{c}5.5 \pm 0.3 \\
\mathrm{NS}^{4} \\
5.1 \pm 0.2\end{array}$ & $\begin{array}{c}267 \pm 14 \\
<0.001 \\
711 \pm 29\end{array}$ & $\begin{array}{c}391 \pm 25 \\
<0.001 \\
952 \pm 41\end{array}$ \\
\hline Low $\mathrm{Na}$ & $\begin{array}{l}7-8 \text { wk } \\
P \text { value } \\
3-4 \text { wk }\end{array}$ & 46 & $\begin{array}{l}189 \pm 5 \\
60 \pm 1\end{array}$ & $\begin{array}{c}13.4 \pm 0.7 \\
<0.005 \\
15.8 \pm 0.4\end{array}$ & $\begin{array}{c}4.9 \pm 0.4 \\
\mathrm{NS} \\
4.2 \pm 0.3\end{array}$ & $\begin{array}{l}56 \pm 5 \\
N S \\
49 \pm 8\end{array}$ & $\begin{array}{c}495 \pm 30 \\
<0.001 \\
962 \pm 72\end{array}$ \\
\hline
\end{tabular}

\footnotetext{
'Mean \pm S.E.

${ }^{2}$ Fluid intake, urine volume, and $\mathrm{Na}$ and $\mathrm{K}$ excretion rates $\left(\mathrm{U}_{\mathrm{Na}} \mathrm{V}\right.$ and $\mathrm{U}_{\mathrm{k}} \mathrm{V}$, respectively) were measured during the $24 \mathrm{~h}$ preceding the experiments; all are expressed per $24 \mathrm{~h}$ per $100 \mathrm{~g}$ body weight.

${ }^{3} P$ values were calculated using the unpaired $t$ test.

${ }^{4} \mathrm{NS}, P>0.05$.
}

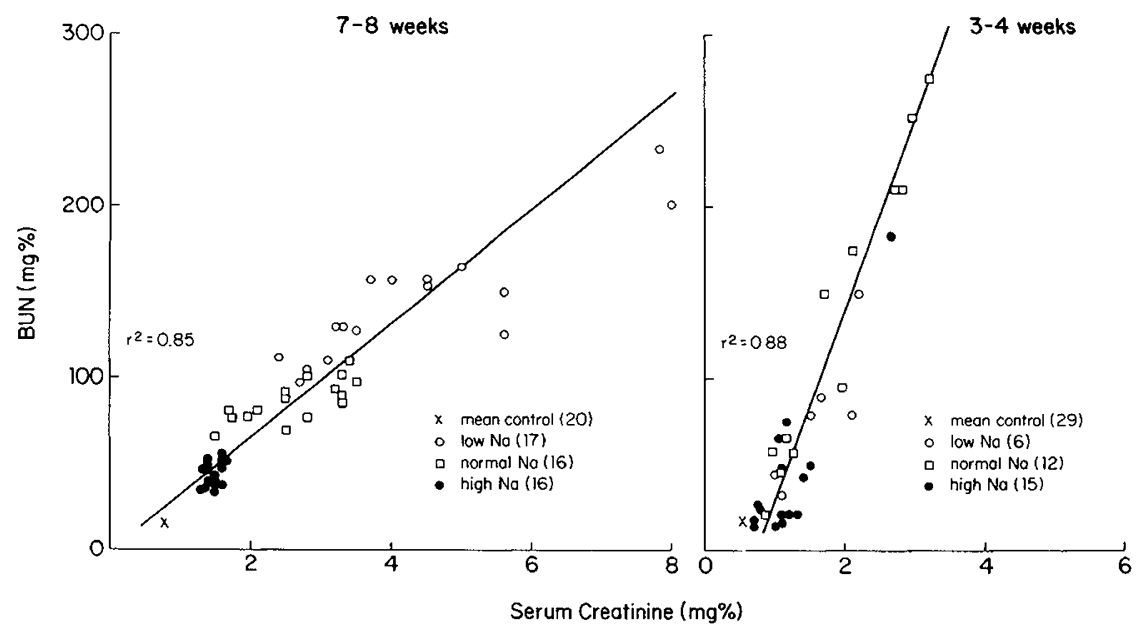

Fig. 1. Correlation of blood urea nitrogen (BUN) with serum creatinine in older (7-8 wk) and younger (3-4 wk) rats given low, normal, and high Na diets. The chemical determinations were performed on samples collected at death or at sacrifice (on the seventh day) following the injection of uranyl nitrate $(2.5 \mathrm{mg} / \mathrm{kg}$ body wt). The mean value for control rats (non-injected) is also shown. 


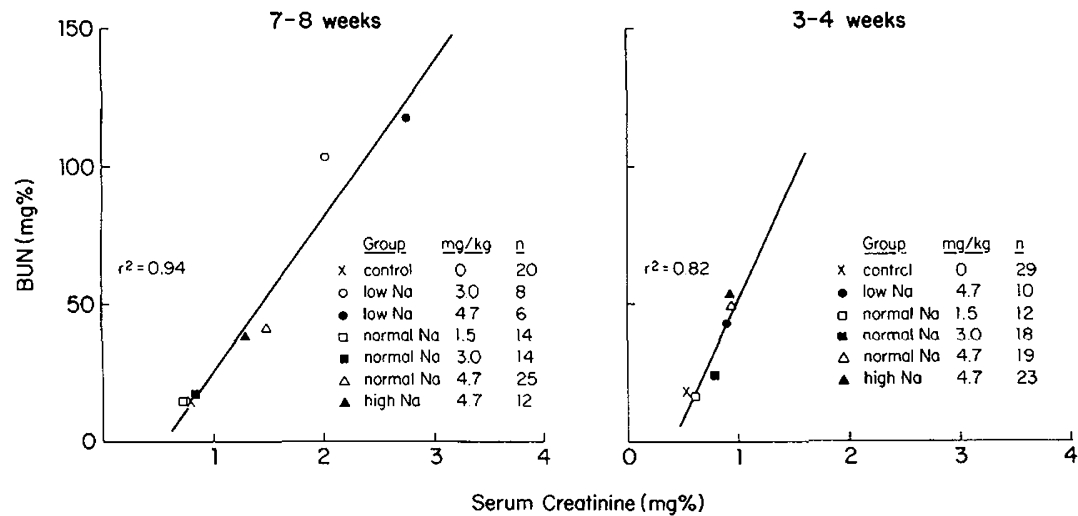

Fig. 2. Correlation of blood urea nitrogen (BUN) with serum creatinine in older and younger rats (7-8- and 3-4-wk-old, respectively) given low, normal, and high $\mathrm{Na}$ diets. The chemical determinations were performed on samples collected at death or at sacrifice (on the fifth day) following the injection of mercuric chloride (at the dosages indicated). Mean values for non-injected (controls) and injected rats are shown; number of rats in each group is indicated.
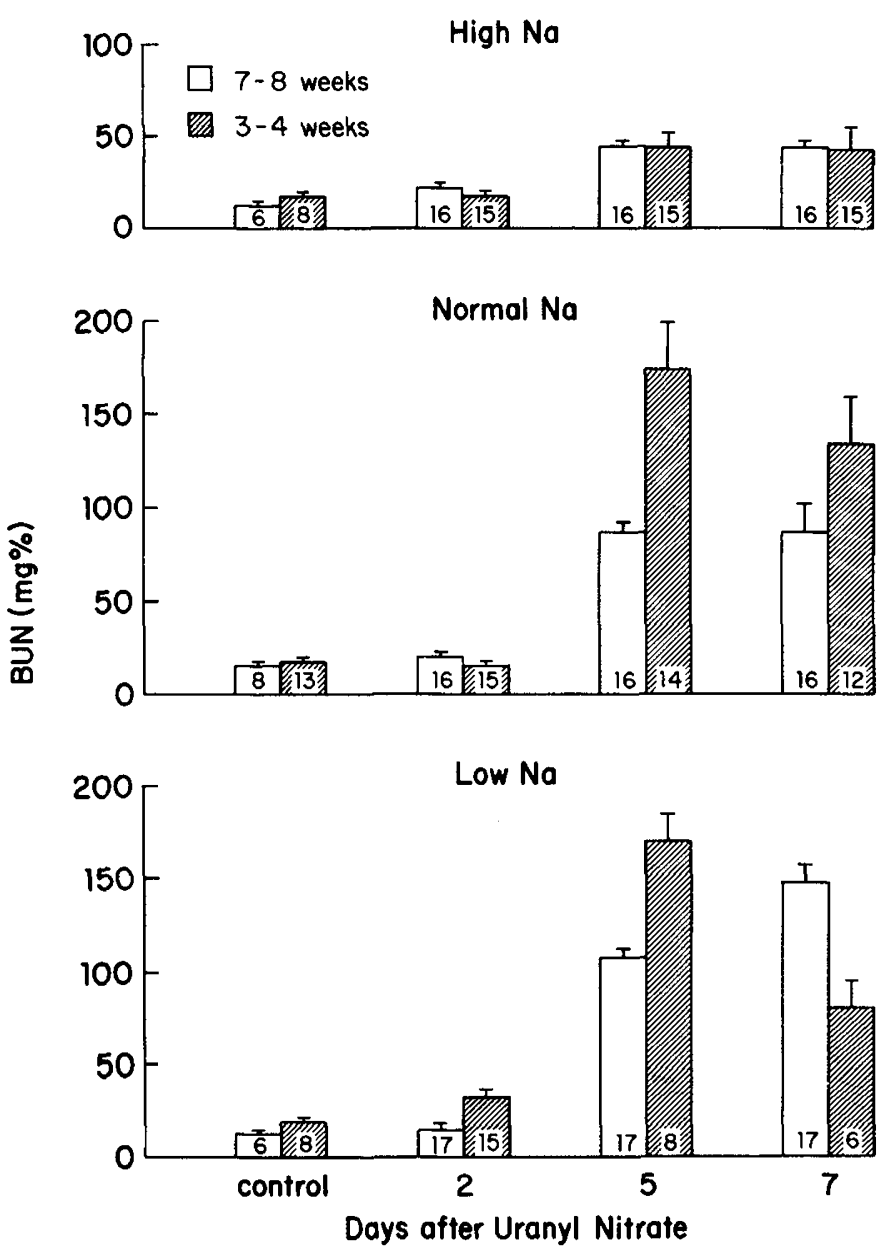

Fig. 3. The development of acute renal failure in older and younger rats (7-8- and 3-4-wk-old, respectively) given low, normal, and high $\mathrm{Na}$ diets as assessed by increases in blood urea nitrogen (BUN) following the injection of uranyl nitrate $(2.5 \mathrm{mg} / \mathrm{kg}$ body wt). Control values were measured in non-injected rats. Means \pm S.E. are shown; number of rats in each group is indicated.

different among the six groups of rats shown in Figure $3(P>$ $0.05)$. In all six groups, mean BUNs on the fifth day were significantly higher than control $(P \leq 0.05$ at most $)$. As assessed by BUN on the fifth day, high $\mathrm{Na}$ diet had a protective effect in rats of both ages; BUN was significantly lower in rats fed the high $\mathrm{Na}$ diet than in rats fed the control diet $(P<0.0001$ and $P<$
0.001 for younger and older rats, respectively). However, the low $\mathrm{Na}$ diet did not enhance the severity of ARF in a clear cut manner. On the one hand, the difference between mean BUNs of 7-8-wkold rats fed the control and the low $\mathrm{Na}$ diets was of borderline significance $(P=0.05)$ whereas the difference in mean BUNs of the 3-4-wk-old rats fed the same two diets was not significant $(P$ $>0.05$ ). On the other hand, mortality rates were higher in 3-4 and $7-8$ wk old rats fed the low $\mathrm{Na}$ diet $(9 / 15$ and $2 / 17$, respectively) than in the corresponding groups fed the control diet $(3 / 15$ and $0 / 16$, respectively). Comparison of these mortality rates, 3-4versus 7-8-wk-old rats, suggests that the younger rats fed normal or low $\mathrm{Na}$ diets were more susceptible to, or had a more severe form of, ARF than the older rats. Indeed, BUNs on the fifth day were higher in the younger groups fed either normal or low $\mathrm{Na}$ diets than in the corresponding older groups $(P<0.0001)$. In contrast, there were no deaths in either younger or older rats fed the high $\mathrm{Na}$ diet and mean BUNs of both age groups on the fifth day were not significantly different $(P>0.05)$.

Figure 4 shows the effect on $\mathrm{HgCl}_{2}$-induced $\mathrm{ARF}$ of variations in dietary $\mathrm{Na}$ in both age groups. As noted above, there was no effect of age or of dietary $\mathrm{Na}$ on baseline BUN; grand averages of BUN were $14.6 \pm 0.4$ and $18.2 \pm 0.6 \mathrm{mg} \%$ for older and younger rats, respectively. Baseline BUN and BUN 2 days after $\mathrm{HgCl}_{2}$ injection were compared using one-way analysis of variance and Scheffe contrasts. By the second day after the $4.7 \mathrm{mg} / \mathrm{kg}$ dose, BUN was increased above baseline in younger rats fed high ( $P$ $<0.03)$, normal $(P<0.001)$ or low $(P<0.0001) \mathrm{Na}$ diets and in older rats fed normal $(P<0.0001)$ and low Na diets $(P<0.0001)$. The increase in BUN of older animals fed the high $\mathrm{Na}$ diet was of borderline significance $(P=0.05)$. An inverse relationship between dietary $\mathrm{Na}$ and the severity of ARF is apparent; BUN was significantly lower in rats fed the high $\mathrm{Na}$ diet than in rats fed the control diet $(P<0.0001$ and $P<0.001$ for $3-4$ - and $7-8$-wk-old rats, respectively), and in turn, BUN was lower in rats fed the control diet than in those fed the low Na diet $(P<0.05$ and $P<$ 0.0001 for 3-4- and 7-8-wk-old rats, respectively). Also, mortality rates were inversely related to dietary $\mathrm{Na}: 3 / 25,13 / 43$, and $15 / 25$ for the younger rats fed high, normal, and low Na diets, and $0 / 12$, $4 / 28$ and $7 / 13$ for the older rats fed these respective diets and given the $4.7 \mathrm{mg} / \mathrm{kg}$ dose.

Figure 4 also shows the $\mathrm{HgCl}_{2}$ dose-response in rats of both ages. The $1.5 \mathrm{mg} / \mathrm{kg}$ dose did not result in a significant increase in BUN on the second day in either 3-4- or 7-8-wk-old rats $(P$ $>0.05$ ); also there were no deaths resulting from this dose in either age group. The $3.0 \mathrm{mg} / \mathrm{kg}$ dose did not elevate BUN significantly in the older rats $(P>0.05)$, but it did in the younger rats $(P<0.01)$. At this dose, $3 / 21$ younger rats and no older rats died. In both age groups, the $4.7 \mathrm{mg} / \mathrm{kg}$ dose increased BUN more than the $3.0 \mathrm{mg} / \mathrm{kg}$ dose $(P<0.001$ and $P<0.0001$ for $3-4$ and 7-8 wk old rats, respectively). 


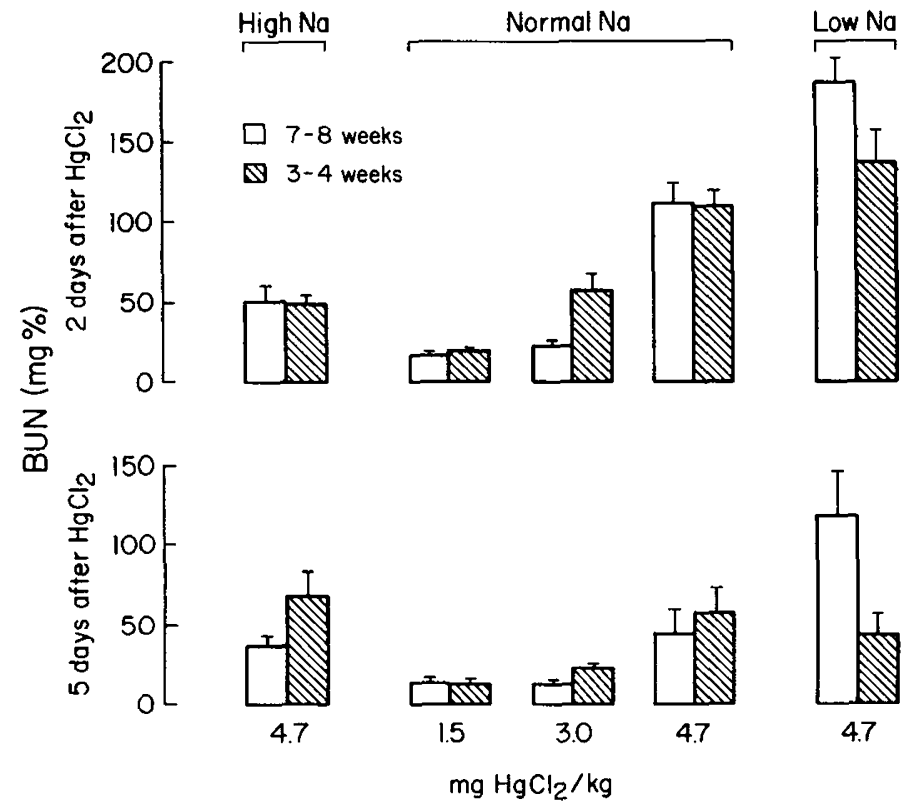

Fig. 4. The development of acute renal failure in older and younger rats (7-8- and 3-4-wk-old, respectively) given low, normal, and high $\mathrm{Na}$ diets as assessed by increases in blood urea nitrogen (BUN) 2 and 5 days following the injection of various doses of mercuric chloride. Means $\pm \mathrm{SE}$ are shown.

As was the case with the UN model, mean BUNs of younger and older rats fed the high $\mathrm{Na}$ diet were not significantly different $(P>0.05)$. However, BUNs were not significantly different between younger and older rats fed the control diet and given the $4.7 \mathrm{mg} / \mathrm{kg}$ dose $(P>0.05)$; moreover, BUN of the younger rats fed the low $\mathrm{Na}$ diet was actually lower than that of the older rats $(P<0.0001)$. This latter difference is somewhat misleading, however; although overall mortality rates of younger and older rats fed the low $\mathrm{Na}$ diet were similar $(15 / 25$ and $7 / 13$, respectively), 5 of the 15 deaths of younger animals occurred during the first day, and in these, BUN at death averaged $136 \pm 9 \mathrm{mg} \%$. Thus, mean BUN in such a circumstance reflects values of the least severely affected.

Comparison of Figures 3 and 4 suggests that ARF developed more rapidly in the $\mathrm{HgCl}_{2}$ model. In the UN model, BUN peaked around the fifth day whereas in the $\mathrm{HgCl}_{2}$ model, it peaked around the second day and by the fifth day, recovery had either begun (BUN had begun to decrease) or the rat had died.

\section{DISCUSSION}

The precise mechanisms by which nephrotoxins such as $\mathrm{HgCl}_{2}$ and UN induce ARF in experimental animals remain to be elucidated $(10,14,16,23,34,35)$. The critical target sites for these nephrotoxins as well as their modes of delivery to these sites remain conjectural $(23,35,37)$. Moreover, the relationships of the various enzymatic, biochemical, structural and functional derangements that occur after nephrotoxin administration are still unclear $(23,25,26,35,37)$. Decreased renal blood flow, tubular obstruction, and backleak of filtrate have all been reported to play major roles $(9,11,14-17,27,34,35,37)$. Regardless of the mechanisms involved, in the mature animal, the level of $\mathrm{Na}$ intake and/or excretion has been demonstrated to have a profound effect on the severity of ARF in several experimental models $(5,7,8,14$, 28 ). Indeed, excellent inverse correlations have been found between $\mathrm{Na}$ excretion in the $24-\mathrm{h}$ period preceeding nephrotoxin administration and the severity of ensuing $\operatorname{ARF}(5,8,14)$.

The results obtained from the older rats of the present studies are consistent with an inverse relationship between severity of ARF (as assessed by either BUN or mortality following induction) and dietary $\mathrm{Na}$ intake and/or excretion. An inverse relationship in the younger groups of rats was not as clear cut. On the one hand, high $\mathrm{Na}$ diet decreased and low $\mathrm{Na}$ diet increased the mortality resulting from injections of either $\mathrm{UN}$ or $\mathrm{HgCl}_{2}$ in the younger rats. On the other hand, although increased $\mathrm{Na}$ intake and/or excretion was associated with a reduced BUN following injection of either $\mathrm{UN}$ or $\mathrm{HgCl}_{2}$, decreased $\mathrm{Na}$ intake and/or excretion was not associated with a significantly increased BUN in either model. At any rate, it can be concluded that increased $\mathrm{Na}$ intake and/or excretion has a protective effect in the younger as well as the older rat.

Certain findings are suggestive of increased susceptibility to, or increased severity of, ARF in the younger rats. First, except for similar mortality rates in younger and older rats fed the low $\mathrm{Na}$ diet and given the $4.7 \mathrm{mg} / \mathrm{kg}$ dose of $\mathrm{HgCl}_{2}$, mortality rates were consistently higher in the groups of younger rats, whether or not they were fed normal or low Na diets, and whether or not they were injected with UN or with the 3.0 or the $4.7 \mathrm{mg} / \mathrm{kg}$ dose of $\mathrm{HgCl}_{2}$. Second, the intermediate dose of $\mathrm{HgCl}_{2}$ had no apparent effect on older rats (no deaths, no significant increase in BUN above baseline) whereas this dose, when given to the younger rats, resulted in three deaths and more than doubled the BUN of the survivors. It should be recognized that these comparisons are only suggestive. Differences in mortality rate might have an alternate explanation, namely, that because of age-related differences in food intake, reducing renal function by a given amount in younger rats produces larger distortions in electrolyte balances (plasma $\mathrm{pH}$ and potassium and phosphate concentrations), and with more drastic consequences, than in older rats. Moreover, direct comparisons of either BUN or $\mathrm{S}_{\mathrm{Cr}}$ between younger and older animals is not completely satisfactory because of differences in basal values and/or age-related differences in food intake per unit body weight. However, the similar values of \% increase in BUN/\% increase in $\mathrm{S}_{\mathrm{Cr}}$ in rats of both age groups suggest that, short of measuring changes in glomerular filtration rate directly, the use of BUN as an index is not inappropriate. It is of interest that, whether mortality or BUN is used as an index of susceptibility or severity, the differences between the 3-4- and the 7-8-wk-old rats of the present study were less dramatic than those observed previously between 2- and 8-wk-old rats (6). Following the $4.7 \mathrm{mg} / \mathrm{kg}$ dose of $\mathrm{HgCl}_{2}$. BUN continued to increase between the second and fifth days in 2-wk-old rats, in contrast to the results presented in Figure 4 for rats 3-4-wk-old. The reason for this difference is not known. Slower elimination of nephrotoxin due to less fully developed glomerular and tubular functions in the 2-wk-old rats $(2,12$, $19-20,22,30,31)$ might have played a role.

In conclusion, although there are age-related differences in the renal handling of $\mathrm{Na}(3,4,24,29,32,33)$ and there may be agerelated differences in the susceptibility to and the severity of ARF, younger rats can be protected against nephrotoxin-induced ARF by increasing their $\mathrm{Na}$ intake and/or excretion. The mechanism is not known. Both long-term and short-term changes in $\mathrm{Na}$ intake and/or excretion are effective in mature rats, and the protective effects are independent of changes in the activity of the reninangiotensin system $(5,7,8,10)$. It has been suggested that a state of sustained solute diuresis may increase the rate of nephrotoxin elimination and minimize prolonged tubular injury and obstruction $(5,7,11,23,26,27,35)$. Whatever the mechanism, that the protective effect can be achieved in the young may have important clinical implications.

\section{REFERENCES AND NOTES}

1. Aperia, A., Broberger, O., Thodenius, K., and Zetterstrom, R.: Renal response to an oral sodium load in newborn full term infants. Acta Paediatr. Scand., 61: 670 (1972).

2. Aperia, A. and Herin, P.: Development of glomerular perfusion rate and nephron filtration rate in rats 17-60 days old. Am. J. Physiol., 228: 1319 (1975).

3. Bengele, H. H. and Solomon, S.: Development of renal response to blood volume expansion in the rat. Am. J. Physiol., 227: 364 (1974).

4. Bengele, H. H. and Solomon, S.: Development of the renal response to blood volume expansion in normal and fast-growing rats. Am. J. Physiol., 231: 832 (1976). 
5. Bidani, A., Churchill, P. C., and Fleischmann, L.: Sodium-chloride-induced protection in nephrotoxic acute renal failure: independence from renin. Kidney Int., 16: 481 (1979).

6. Bidani, A., Churchill, P. C., Fleischmann, L., and Becker-McKenna, B.: $\mathrm{HgCl}_{2}$ induced acute renal failure in the developing rat. Pediatr. Res., 14: 183 (1979).

7. Bidani, A., Churchill, P. C., McDonald, F. D., and Fleischmann, L.: Glycerolinduced myohemoglobinuric acute renal failure in the pregnant rat. Nephron, 26: 35 (1980)

8. Bidani, A. K., Fleischmann, L. E., Churchill, P., and Becker-McKenna, B.: Natriuresis-induced protection in acute myohemoglobinuric renal failure without renal cortical renin content depletion in the rat. Nephron, 22: 529 (1978).

9. Blantz, R. C.: The mechanism of acute renal failure after uranyl nitrate. J. Clin. Invest., 55: 621 (1975).

10. Churchill, P. C., Bidani, A., Fleischmann, L., and Becker-McKenna, B.: $\mathrm{HgCl}_{2}-$ induced acute renal failure in the Golblatt rat. J. Lab. Clin. Med., 91; 660 (1978).

11. Cronin, R. E., de Torrente, A., Miller, P. D., Bulger, R. E., Burke, T. J., and Schrier, R. W.: Pathogenic mechanisms in early norepinephrine-induced acute renal failure: functional and histological correlates of protection. Kidney Int., 14: 115 (1978).

12. de Rouffignac, C. and Monnens, L.: Functional and morphologic maturation of superficial and juxtamedullary nephrons in the rat. J. Physiol. (Lond.), 262: 119 (1976).

13. Dixon, W. J. and Massey, F. J., Jr.: Introduction to Statistical Analysis. Chapter 8, 10, and 15. (McGraw-Hill Book Company, New York, NY 1969).

14. Flamenbaum, W.: Pathophysiology of acute renal failure. Arch. Intern. Med., 131: 911 (1973)

15. Flamenbaum, W., Hamburger, R. J., Huddleston, M. L., Kaufman, J., McNeil, J. S., Schwartz, J. H., and Nagel, R.: The initiation phase of experimental acute renal failure: an evaluation of uranyl nitrate-induced acute renal failure in the rat. Kidney Int., 10: S115 (1976).

16. Flamenbaum. W., Huddleston, M. L., McNeil, J. S., and Hamburger, R. J.: Uranyl nitrate-induced acute renal failure in the rat: micropuncture and renal hemodynamic studies. Kidney Int., 6: 408 (1974).

17. Flamenbaum, W., McDonald, F. D., DiBona, G. F., and Oken, D. E.: Micropuncture study of renal tubular factors in low dose mercury poisoning. Nephron, 8: 221 (1971)

18. Goldsmith, D. I., Drukker, A., Blaufox, M. D., Spitzer, A., and Edelmann, C. M., Jr.: Response of the neonatal canine kidney to acute saline expansion. In: K. ZumWinkel, M. D. Blaufox, and J. L. Funck-Brentano, Eds., Radionuclides in Nephrology. pp. 45-51. (Thieme, Stuttgart, 1975).

19. Horster, M. and Larsson, L.: Mechanisms of fluid absorption during proximal tubule development. Kidney Int., 10: 348 (1976).

20. Horster, M. and Lewy, J. E.: Filtration fraction and extraction of PAH during neonatal period in the rat. Am. J. Physiol., 219: 1061 (1970).

21. Horster, M. and Valtin, H.: Postnatal development of renal function: micropuncture and clearance studies in the dog. J. Clin. Invest., 50: 779 (1971).

22. Jose, P. A., Slotkoff, L. M., Lillienfield, L., Calcagno, P., and Eisner, G. M.:
Sensitivity of neonatal renal vasculature to epinephrine. Am. J. Physiol., 226 : 796 (1974).

23. Kirschbaum, B. B., Sprinkle, F. M., and Oken, D. E.: Renal function and mercury level in rats with mercuric chloride nephrotoxicity. Nephron, 26: 28 (1980).

24. Kleinman, L. I.: Renal sodium reabsorption during saline loading and distal blockade in newborn dogs. Am. J. Physiol., 228: 1403 (1975).

25. Kleinman, J. G., McNeil, J. S., Schwartz, J. H., Hamburger, R. J., and Flamenbaum, W.: Effect of dithiothreitol on mercuric chloride and uranyl nitrateinduced acute renal failure in the rat. Kidney Int., 12: 115 (1977).

26. Lameire, R., Ringoir, S., and Leusen, I.: Effect of variation in dietary $\mathrm{NaCl}$ intake on total and fractional renal blood flow in the normal and mercuryintoxicated rat. Circ. Res., 39: 506 (1976).

27. Mauk, R. H., Patak, R. V., Fadem, S. Z., Lifschitz, M. D., and Stein, J. H.: Effect of prostaglandin $\mathrm{E}$ administration in a nephrotoxic and a vasoconstrictor mode of acute renal failure. Kidney Int., 12: 122 (1977).

28. McDonald, F. D., Thiel, G., Wilson, D. R., DiBona, G. F., and Oken, D. E.: The prevention of acute renal failure in the rat by long term saline loading: a possible role of the renin angiotensin axis. Proc. Soc. Exp. Biol. Med., 131:610 (1969).

29. Merlet-Benichou, C. and de Rouffignac, C.: Renal clearance studies in fetal and young guinea pigs: effect of salt loading. Am. J. Physiol., 232: F178 (1977).

30. Potter, D., Jarrah, A., Sakai, T., Harrah, J., and Holliday, M. A.: Character of function and size in kidney during normal growth of rats. Pediatr. Res., 3: 51 (1969).

31. Speller, A. M. and Moffat, D. B.: Tubulo-vascular relationships in the developing kidney. J. Anat. 123: 487 (1977).

32. Spitzer, A.: Renal Physiology and Functional Development. In: C. M. Edelmann, Jr. Ed., Pediatric Kidney Disease. pp. 49-560 (Little, Brown and Company, Boston, MA 1978).

33. Spitzer, A. and Schoeneman, M.: Sodium reabsorption during maturation (abstract). Kidney Int., 10: 598 (1976).

34. Stein, J. H., Gottschall, J., Osgood, R. W., and Ferris, T. F.: Pathophysiology of a nephrotoxic model of acute renal failure. Kidney Int., 8: 27 (1975).

35. Stein, J. H., Lifschitz, M. D., and Barnes, L. D.: Current concepts on the pathophysiology of acute renal failure. Am. J. Physiol., 234: F171 (1978).

36. Wallenstein, S., Zucker, C. L., and Fleiss, J. L.: Some statistical methods useful in Circulation Research. Circ. Res., 47: 1 (1980).

37. Zalme, R. C., McDowell, E. M., and Nagle, R. B.: Studies on the pathophysiology of acute renal failure. II. A histochemical study of the proximal tubule of the rat following administration of mercuric chloride. Virchows Arch. Abt. B. Zellpath., 22: 197 (1976).

38. Requests for reprints should be addressed to: Dr. Anil Bidani, Division of Nephrology, Rush-Presbyterian St. Luke's Medical Center, 1753 West Congress Parkway, Chicago, IL 60612.

39. This research was supported by a grant from the Skillman Foundation of Detroit. 40. Received for publication November 17, 1980.

41. Accepted for publication August 20, 1981.

\section{ANNOUNCEMENT}

The International Center for Interdisciplinary Studies of Immunology at Georgetown University will be holding an international workshop on "ACUTE DIARRHEA: ITS NUTRITIONAL CONSEQUENCES IN CHILDREN" at the Pan American Development Foundation in Washington, D.C. on May 7-10, 1982. The conference, which is being co-sponsored by the Nestle Corporation and the Pan American Development Foundation, will bring together a group of internationally renowned authorities in the fields of immunology and nutrition and will include the most recent advances in acute diarrhea in infancy including epidemiology, pathogenesis, therapy and prevention. A plenary session summarizing the contents of the workshop will be held on May 10 to which all interested individuals are cordially invited to attend. For further information, contact: Ms. Barbara Claudy, International Center for Interdisciplinary Studies of Immunology, Georgetown University, School of Medicine, Washington, D.C. at (202) 625-7437. 